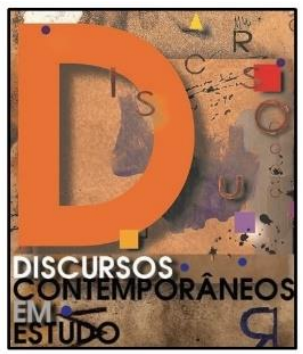

\title{
PAINÉIS MULTIMODAIS: PINCELADAS SOBRE RESSEMIOTIZAÇÃO NA ESCOLA BILÍNGUE DE TAGUATINGA - DISTRITO FEDERAL
}

Eduardo Brasil (UnB) ${ }^{1}$

No presente trabalho, pretende-se lançar luz sobre a maneira como as modalidades oral e escrita são ressemiotizadas para a linguagem visual na Escola Bilíngue - Libras e Português escrito, de Taguatinga (EBT). O corpus é constituído pelo mural do pátio escolar, produzido pelos próprios alunos surdos da EBT, como produto final da aula de português escrito. Uma vez que os objetivos secundários deste artigo giram em torno da identificação dos recursos semióticos empregados na integração multimodal de sentidos, a qual estabelece a comunicação dentro e fora da escola, separei também como dado de análise um dos vários enquadres pintados no muro da escola. A teoria da Multimodalidade constitui a base teórica deste trabalho, sob o amparo das categorias da Gramática Visual de Kress e van Leeuwen (2006), quais sejam os participantes interativos e representados, a saliência, o real versus o ideal, o dado versus o novo e atributos simbólicos. Os resultados apontam que a ressemiotização só é possível porque o princípio de complementaridade intersemiótica (ROYCE, 2007) atua na composição dos murais, mesclando as modalidades visuais e verbais, de forma a conferir mais dinamismo à modalidade escrita do português - língua alvo do aprendiz surdo.

Palavras-chave: ressemiotização; multimodalidade; surdez.

This paper intends to shed light on the way the oral and written modalities are resemiotizedinto the visual language in the Bilingual School - Brazilian sign language and written Portugueseof Taguatinga (BST). The corpus consists of the mural in the schoolyard, fashioned by the deaf students of the BST as the final project of the "Written Portuguese' class. Once the secondary objectives of this article revolve around the identification of the semiotic resources applied to themultimodal integration of meaning, which fosters communication inside and outside the school, I also singled out as datum for this analysis one of the several frames painted on the school wall. The theory of Multimodality is the theoretical basis of this work, upheld by the analytical categories of the Grammar of Visual Design by Kress and van Leeuwen (2006), namely the interactive and represented participants, salience, the real versus the ideal, the given versus the new, and symbolic attributes. The results show that resemiotization is only possible because the principle of intersemiotic complementarity (ROYCE, 2007) operates in the composition of the murals, merging visual and verbal forms, in order to give more dynamism to written mode of Portuguese, which is the target language of the deaf apprentice.

Keywords: resemiotization; multimodality; deafness.

\footnotetext{
${ }^{1}$ Mestre em Linguística pela Universidade de Brasília (UnB); membro da ALED e do CEPADIC; desenvolve pesquisas acadêmicas sobre produção de materiais didáticos, identidade e surdez.
} 


\section{Introdução}

Misteriosos são os caminhos percorridos pelos profissionais da educação que ensinam surdos no Brasil. Como professor aspirante a embarcar nesta jornada, minhas pesquisas têm apontado dificuldades, preocupações e desafios frente ao desconhecido e complexo universo da cultura surda: as várias identidades surdas, a língua de sinais e a leitura visual (em oposição à experiência acústica) do mundo à nossa volta. Esses são alguns dos elementos essenciais que precisam ser entendidos com muita sensibilidade por qualquer profissional ouvinte que lide com letramento bilíngue de surdos.

Relato, neste artigo, o meu contato com os professores da Escola Bilíngue - Libras e Português escrito (EBT), de Taguatinga - DF, que se dispuseram a compartilhar suas experiências e sabedoria no assunto. Ao abrirem os portões da escola modelo, na referida cidade-satélite de Brasília, eles possibilitaram os meus primeiros contatos com o mundo visual lato sensu, pois as belíssimas pinturas em torno dos muros da escola, bem como os que se encontram exibidos nos pátios, captaram-me pelos olhos e prenderam-me pelo coração.

Assim, proponho-me a entender como se estabelece o percurso de ressemiotização da linguagem oral e escrita para a linguagem visual na EBT. Para tanto, é necessário identificar quais recursos semióticos são utilizados para a integração multimodal de sentidos, a qual diz respeito às três modalidades em jogo aqui, quais sejam a visual, a verbal e a escrita. Além disso, pela posição em que esses murais se encontram, ou seja, dentro e fora da escola, lanço enfoque sobre como a comunicação é estabelecida sob estas duas projeções discursivas das práticas sociais construídas na EBT, interna e externamente falando.

O corpus é constituído pelo mural produzido pelos alunos como produto final da aula de português escrito. Também será utilizado um dos vários enquadres pintados no muro da escola. 


\section{Bases Teóricas}

\section{A surdez e a Teoria da Multimodalidade}

De acordo com Kress e van Leeuwen (1996, 2006), assim como ocorre com o sistema linguístico, a linguagem visual possui estruturas que revelam interpretações específicas sobre as relações e interações entre participantes. Os significados pertencem à cultura e não a modos semióticos específicos, que podem ser linguísticos, auditivos, visuais, gestuais e espaciais. Portanto, a imagem, o layout, a música, o gesto, o ato de fala e o evento escrito são exemplos de modos usados na representação e na comunicação. A maneira como os significados podem ser mapeados nos diversos modos semióticos, por exemplo, a forma como alguma coisa pode ser dita tanto visualmente quanto verbalmente, outras apenas visualmente e, da mesma forma, outras somente pelo modo verbal, também são explicados sob a égide da cultura e da história de um determinado grupo social.

Esse lastro histórico-cultural é a interface com a Análise de Discurso Crítica (ADC), já que, segundo Fairclough (2001), o discurso é a força constitutiva das diversas esferas da estrutura social, das relações sociais entre indivíduos, da formação de sistemas de conhecimento e crenças, bem como de relações de poder e hegemonia. 0 que pode ser observado na produção dos murais da EBT é a materialização de discursos que estão disponíveis pelos produtores de texto que atuam nesta escola. Para a ADC, o texto é a materialidade do discurso, o qual tanto molda a sociedade como também é, por ela, moldado.

Nesta perspectiva, Kress e van Leeuwen (1996) propõem a análise de textos multimodais, cujo significado é constituído por mais de um modo semiótico. A Multimodalidade, nesse sentido, é vista como fenômeno. Em contrapartida, como teoria, ela traz a proposta de análise de textos verbais e imagéticos, de acordo com categorias gramaticais. Há algumas questões importantes a respeito disso, apontadas por Kress e van Leeuwen (1996, p. 177):

- Os produtos dos diferentes modos devem ser analisados separadamente ou de forma integrada?

- Os significados da totalidade do texto devem ser tratados como a soma dos significados das partes? 
- As partes devem ser analisadas como que interagindo umas com as outras e, portanto, afetando-se coletivamente?

Em se tratando de ensino bilíngue para surdos, este último ponto é de fundamental importância, pois ele é chamado de Princípio de Integração de Recursos Multimodais. A modalidade se refere a cada uma das semioses que compõem a linguagem ${ }^{2}$. A escrita é uma semiose típica das línguas oral-auditivas. Nela, há recursos semióticos específicos como, por exemplo, o tamanho e o tipo da fonte, utilizada na escrita. É relevante salientar que isso só é um recurso semiótico significativo porque há diferentes fontes para títulos, notas de rodapé, subtítulos, etc. Na fala, o som e a rima também são recursos semióticos. Já no visual, a luminosidade, as cores, as linhas divisórias, o tamanho e o formato são os recursos característicos deste modo. Para as línguas de sinais, que são vísuo-espaciais, os recursos semióticos do modo espacial, como o movimento e a direção, desempenham papel importante, ao passo que a combinação dos vários modos semióticos é o principal recurso semiótico do modo espacial. Portanto, a confluência de modalidades mostra o papel vital do Princípio de Integração Multimodal para que os textos sejam compreendidos em sua totalidade.

Os surdos, indivíduos predominantemente visuais, encontram-se na interseção entre o letramento visual, já que são falantes naturais da língua de sinais, e o letramento formal do português como segunda língua, em sua modalidade escrita. 0 letramento bilíngue garante ao surdo o livre exercício de sua cidadania; portanto, o entendimento de como ocorre a transposição de elementos de uma semiose a outra é o ponto-chave deste artigo.

\footnotetext{
${ }^{2}$ Faz-se necessário esclarecer a maneira como articulo os conceitos de semiose e multimodalidade, pois pode-se facilmente confundir ambos os termos, dependendo do contexto em que são usados. Para tanto, recorro a van Leeuwen $(2005$, p. 3): recursos semióticos são ações ou artefatos que utilizamos para nos comunicarmos, quer sejam produzidos fisicamente - com nosso aparelho fonador; com os músculos que movimentamos para criar expressões faciais e gestos, etc. - ou com o uso de tecnologia - com caneta, tinta e papel; com o software e hardware de um computador; com tecidos, tesouras e máquinas de costurar, etc. Tradicionalmente, são chamados de 'signos'. Por exemplo, a testa franzida seria um símbolo de contrariedade, a cor vermelha, um sinal de perigo, etc. Já na página 179, van Leeuwen (2005) introduz quatro maneiras nas quais diferentes tipos de recursos semióticos são integrados para formar textos multimodais e eventos de comunicação, quais sejam o ritmo; a composição; a junção de tempo e espaço; e o diálogo. Apesar de esmiuçar cada uma dessas dimensões separadamente, elas nunca ocorrem de maneira isolada. Por exemplo, embora o ritmo se sobressaia em mídias de base temporal e a composição, por sua vez, em mídias de base espacial, em um filme, ambas se combinam.
} 


\section{Surdez e Ressemiotização}

A ressemiotização diz respeito à recontextualização de significados que saem de uma modalidade a outra. ledema (2003) traça um paralelo entre a Multimodalidade e a ADC, por meio de Halliday e a Linguística Sistêmico-Funcional (LSF) para elucidar como foi possível chegar à ressemiotização. Nela, há todo um conjunto de procedimentos analíticos que tem por fim analisar os modos de conversão de uma semiose em outra. Ainda segundo ledema (2003), as semioses são símbolos, resultados de processos socialmente construídos, jamais isolados. O texto passa a ser analisado como modo de ação social e a língua é vista como sendo semiose social.

ledema (2003) postula que a ressemiotização brotou dos avanços da tecnologia, pois o espaço virtual possibilitou a fusão da língua oral com a escrita, além de imagens e sons. Essa junção de modos fez com que as fronteiras tradicionais entre os papéis alocados por eles fossem revistos e amenizados, uma vez que a tecnologia deu origem a gêneros híbridos, constituídos de vários modos e que, portanto, aproveitam a potencialidade de todos eles, abrindo a possibilidade de rever parâmetros que outrora se encontravam fixos. No esteio da revolução tecnológica, a globalização também ajudou a suavizar diferenças culturais. Como reflexo dessas tendências, o desenvolvimento multissemiótico possibilitou que mais atenção fosse dada a outras semioses, além da língua e redefiniu parâmetros que não se encontram mais de forma linear e hierarquizada, mas que agora são recombinadas livremente, de maneira circular e seriada.

Um dos exemplos mais marcantes trazidos por ledema (2003) é a ressemiotização do simples desejo de se manter a porta fechada:

- $\quad$ pelo modo verbal, pode-se pedir para alguém fechar a porta ao entrar ou sair;

- pelo visual, pode-se colocar uma placa com a mensagem "mantenha a porta fechada";

- pela ressemiotização, pode-se utilizar um dispositivo hidráulico de fechamento automático de porta, o qual mostra os três recursos falando a mesma coisa.

Em suma, a função de cada recurso semiótico é situacional. Deste modo, sua funcionalidade vai se ressemiotizando de acordo com o contexto e cada transposição requer um olhar analítico sobre o processo: como o significado era construído antes e 
como o é agora. Acredito ser também pertinente mencionar o potencial de significação dos diferentes textos. Dentre os vários recursos semióticos que estão funcionando em conjunto, há consistência metafuncional na junção de todos eles, o que nos leva a entender o motivo pelo qual, às vezes, um se sobressai em relação ao outro, dependendo da modalidade que esteja mais proeminente.

Contudo, ledema (2003) traz um alerta para o fato de que nem tudo o que é possível realizar por meio da representação linguística pode ser realocado no visual e vice-versa. O visual semiótico é geralmente contínuo, sensorial, espacial, enquanto que a língua é descontínua, abstrata, linear no tempo, apresentando estritas convenções sintáticas. A ressemiotização privilegia diferentes domínios da experiência humana, principalmente a dimensão da leitura visual e constitui, desta forma, uma perspectiva complementar da Multimodalidade.

\section{Corpus e categorias de análise}

Os dados são representados por duas fotografias: a primeira é retirada de uma das várias pinturas do muro (FIGURA 1), a qual batizo de "Movimento surdo pela educação"; (FIGURA 2), já que a orientação de leitura, na nossa cultura ocidental, é feita da esquerda para a direita e esta é a primeira frase de destaque no painel.

Figura 1 - Pinturas no muro da EBT

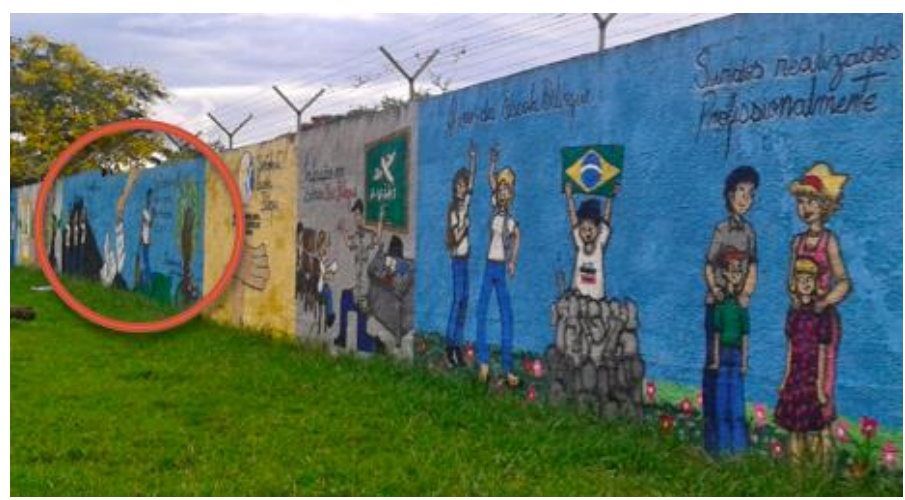

Fonte: Foto do muro tirada pelo autor, para este trabalho, em 13/5/2015. 
Figura 2 - Destaque de imagem na composição da Figura 1

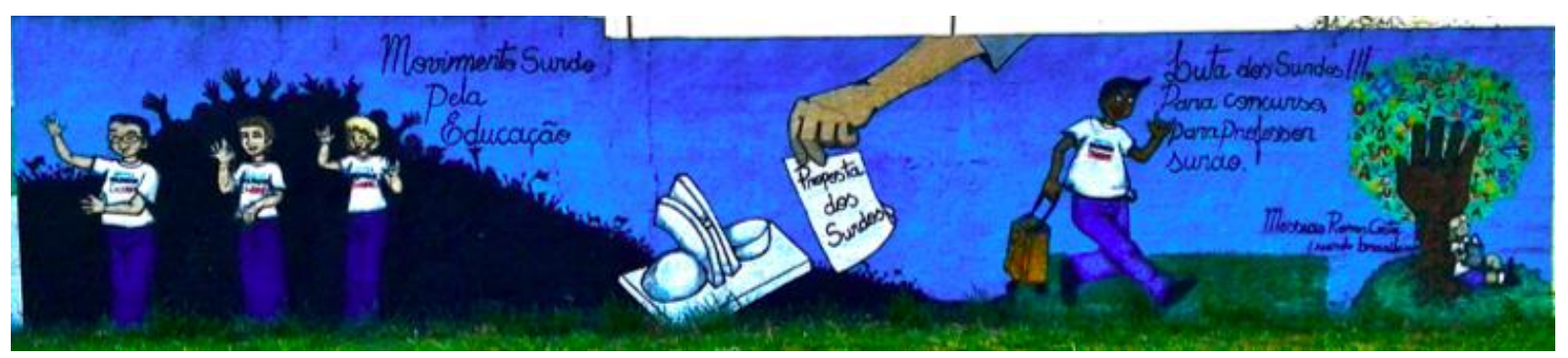

Fonte: foto do muro da EBT, tirada pelo autor, para este trabalho, em 13/5/2015.

Figura 3 - Categorias de análise (muro)

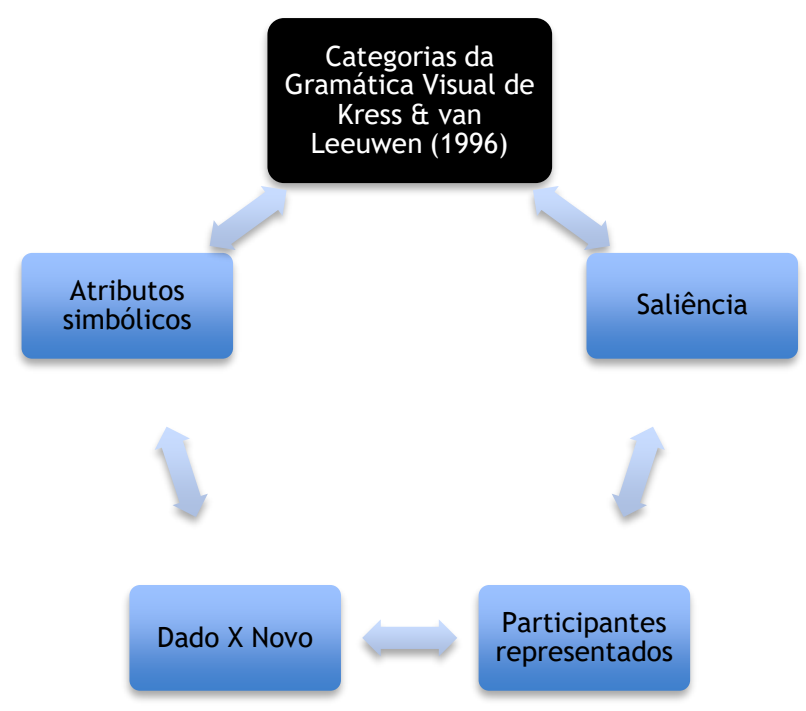

Fonte: Elaborado pelo autor.

O motivo pelo qual escolho este recorte é o forte destaque que a narrativa visual deste painel dá ao processo de letramento comunitário, para fora dos muros desta escola, em busca da sensibilização da população quanto à importância da formação cidadã do indivíduo surdo. Ouso dizer que, especificamente, em se tratando deste quadro do muro, há o registro documental (e visual) importantíssimo sobre o nascimento desta escola. Assim como todos nós, ao nascer, temos o registro de que existimos, por meio da Certidão de Nascimento, na qual há a narrativa escrita da vinda do bebê 
nascituro ao mundo, este pedacinho do muro é a foto da Cédula de Identidade da EBT. O trecho da entrevista3 feita com a coordenação pedagógica da escola justifica essa ideia:

E então nós estávamos neste modelo, no Educacional 6. Então pra ser algo ainda de conquista era a Escola Bilíngue, com uma proposta toda adequada pro surdo. Aí quando foi éééé... criou em julho de 2013. Mas foi todo um movimento, teve um movimento nacional, aí juntando a este movimento nacional o movimento do DF se apoiou pra organizar a Escola Bilíngue própria do DF... Escreveu o projeto, e tudo, né, encaminhou... na verdade nós entregamos este projeto com representantes do Ensino Médio, Ensino Fundamental e anos iniciais e anos finais, não é, no Ensino Fundamental, então tínhamos representantes professores de todas as modalidades e os surdos, também, com a representação da Feneis ${ }^{4}$. E foi entregue esse projeto em 2011, à Secretaria de Educação. Até hoje nós não recebemos resposta desse projeto que foi protocolado e entregue. Então, aí o caminho foi outro, foi pela Câmara Legislativa. Daí teve o apoio e daí toda a assessoria jurídica do deputado Wellington Luiz, que abriu as portas mesmo para essa comissão e aí elaborou um projeto de lei, ouvindo esse grupo, né, eles só nos deram assessoria jurídica e aí,ééé... o projeto foi aprovado e este projeto estabelece as diretrizes para a Escola Bilíngue.

Antes de apresentar a segunda parte dos dados, gostaria de esclarecer sobre a importância dos murais como gênero discursivo. Segundo Bakhtin (1997), gêneros discursivos são tipos de enunciados relativamente estáveis e normativos, vinculados a situações típicas da comunicação social. A lucidez com que ele articula os conceitos de gêneros textuais atravessa os tempos e nos alcança nos dias de hoje, na era das mídias digitais, as quais semeiam novos gêneros textuais. 0 caráter não estático e constantemente frutífero dessas práticas discursivas pode ser visto da seguinte forma:

como tipos temáticos, estilísticos e composicionais dos enunciados individuais, os gêneros se constituem historicamente a partir de novas situações de interação verbal (ou outro material semiótico) da vida social que vão (relativamente) se estabilizando, no interior das diferentes esferas sociais (RODRIGUES, 2004, p. 423).

Diante disso, os gêneros são constituídos por um recorte discursivo cujos textos (orais, escritos ou imagéticos) refletem, realizam e saciam anseios comunicativos reais da vida em sociedade. Embora a classificação de gêneros não seja o foco desta discussão, a imbricação de gêneros multimodais é importante pela força do potencial de

\footnotetext{
${ }^{3}$ Transcrição do trecho da entrevista realizada no dia 01/7/2015, com a diretora pedagógica da EBT, no qual pergunto sobre como surgiu a escola.

${ }^{4}$ Federação Nacional de Educação e Integração dos Surdos.
} 
significado que cada recurso semiótico traz. Quando comparamos o uso de murais em escolas cujos alunos são ouvintes, há certo potencial de significação vinculado a eles, mas como a EBT recebe um público surdo, a proeminência do visual não segue a mesma lógica de um público ouvinte. Entendo que, neste caso, o percurso gerativo de sentidos é predominantemente visual. É por isso que o gênero mural é mais representativo para falantes de línguas vísuo-espaciais, pois refletem a cultura visual desses alunos.

As fotografias a seguir (FIGURAS 4 e 5) foram tiradas do mural que fica no pátio da EBT, produzido pelos alunos, sobre o “Dia D - Dia Nacional sem Bullying”. A Figura 6 refere-se às categorias empregadas para a análise desses dados.

Figuras 4 e 5 - Mural do pátio escolar (Dia D - Dia Nacional sem Bullying)
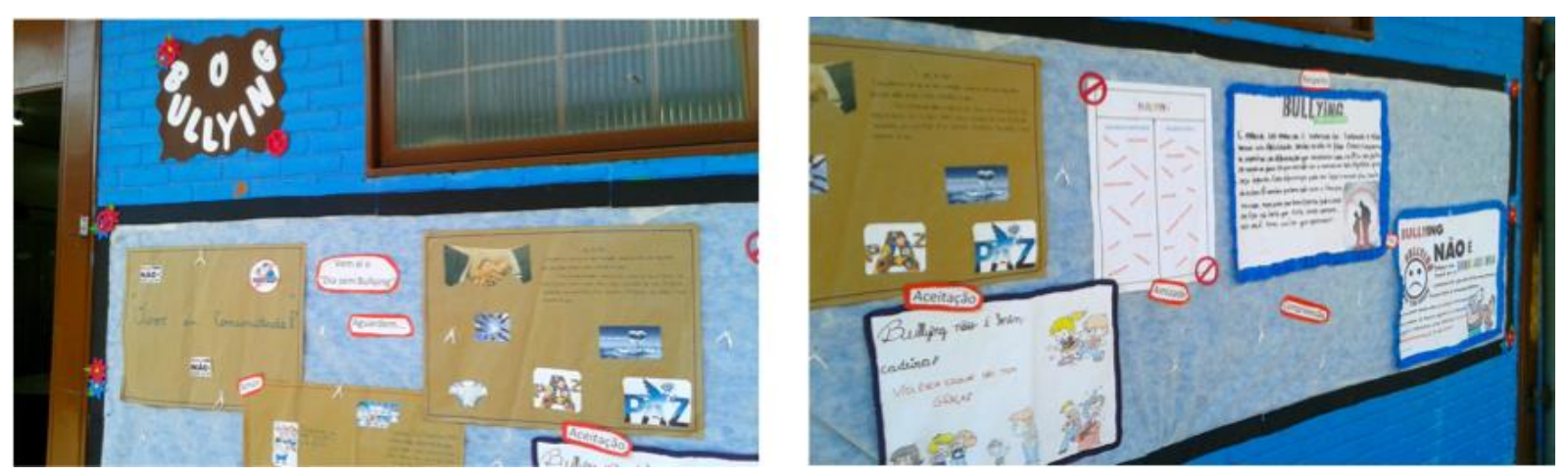

Fonte: Kit enviado pela professora de português, via e-mail, em 19/12/2015.

Figura 6 - Categorias de análise (mural)

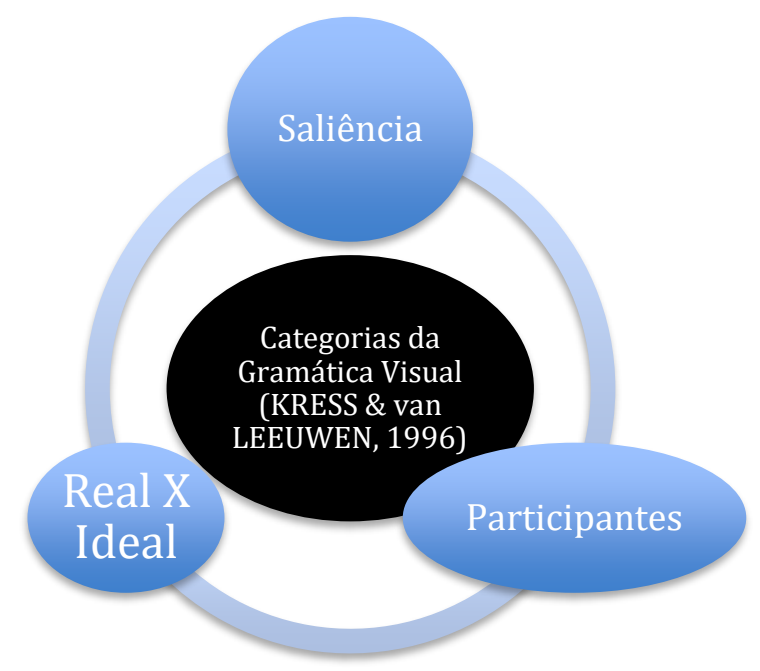

Fonte: Elaborado pelo autor. 
As fotos do mural foram cedidas pela professora de português escrito, via e-mail, que também, gentilmente, disponibilizou o plano de aula que guiou a produção deste material, intitulado "Sequência Didática", do qual extraio as principais informações:

As aulas de português como segunda língua ocorrem obedecendo à seguinte sequência didática, as quais chamamos de 'Os dez passos':

- $1^{\circ}$ - Incentivo que remeta ao tema do texto, por meio de brincadeiras, debates, pesquisas, vídeos e outros;

- $2^{\circ}$ - Primeiro contato com o texto escrito em que os alunos fazem a leitura sem o apoio da professora e sublinham as palavras e expressões desconhecidas;

- $\quad 3^{\circ}$ - Estudo do vocabulário relativo ao texto, por meio de frases do próprio texto (nível I) e frases em que as palavras aparecem nele e em outros contextos da língua (demais níveis). Esse estudo é feito com o uso de imagens;

- $4^{\circ}$ - Segundo contato com o texto escrito, com o apoio e explicações complementares da professora e dos próprios alunos, que nesse ponto e após o estudo vocabular, já conseguem entender os significados que antes lhes eram obscuros;

- $5^{\circ}$ - Exercícios escritos de vocabulário e correção, seguidos de exercícios escritos de interpretação do texto e correção;

- $6^{\circ}$ - Produção de texto de acordo com o tema debatido e estudado através do texto;

- $7^{\circ}$ - Estudo gramatical a partir dos erros mais frequentes das produções dos alunos;

- $8^{\circ}$ - Exercícios gramaticais de acordo com o contexto do texto e o que foi descoberto pelos alunos e solidificado pela professora, seguidos da correção desses exercícios;

- $\quad 9^{\circ}$ - Reescrita em grupo, individual ou coletiva das produções dos alunos;

- $10^{\circ}$ Conclusão do trabalho relativo ao texto por meio de teatro, confecção de murais e outros.

A justificativa deste dado para análise é que, no meu entendimento do plano de aula descrito anteriormente, as práticas pedagógicas na EBT estão ancoradas em constantes exercícios de ressemiotização. Contudo, o mural é a ressemiotização, por excelência, dos textos verbais, nos quais é trabalhada a língua alvo destes alunos - o português escrito, para a linguagem visual, modalidade que permeia, predominantemente, as práticas discursivas dos surdos. Além do mais, ressalto a importância do discurso como principal ferramenta de empoderamento, pois as práticas discursivas em mudança contribuem para transformar o conhecimento (até mesmo as crenças e o senso comum), as relações sociais e as identidades sociais (FAIRCLOUGH, 2001, p. 27).

O Dia Nacional de Combate ao Bullying foi sancionado pela Lei n. 13.277/16, tendo o dia 7 de abril como data oficial, na qual a sociedade carioca, tristemente, vivenciou o 
massacre de 12 estudantes em uma escola de Realengo. Segundo as reportagens ${ }^{5}$, 0 assassino em série era ex-aluno do colégio e sofreu constantes instâncias de bullying durante o período escolar. É com profunda admiração pela iniciativa de professores assim que retomo minha fé na escola, lugar de diálogos, reflexões e capazes de promover transformações sociais.

Para encerrar esta seção, acredito que a depuração desses dados, amparada pelas categorias de análise da Gramática Visual de Kress e vanLeeuwen (1996) e pelo princípio da integração de recursos semióticos multimodais será de grande valia para entender as bases do letramento bilíngue de surdos, as quais pressupõem a ressemiotização da linguagem oral e escrita para a linguagem visual.

\section{Análise dos dados}

A fim de traçar o esboço inicial do esteio metodológico, o quadro a seguir resume as categorias que escolho como sendo as mais relevantes para a análise desses dois textos multimodais. Acredito que os esforços analíticos que guiam trabalhos com textos desse tipo, dentro de uma perspectiva funcional, devem sempre partir da materialidade dos dados para a observação do funcionamento dos recursos semióticos empregados, quais princípios os regem e o que está em destaque. Estas são pistas significativas sobre qual é o real interesse do produtor dos signos.

Quadro 1 - detalhamento das categorias de Kress e Van Leeuwen (1996) aplicadas aos murais

\begin{tabular}{|c|l|}
\hline \multicolumn{1}{|c|}{ PARTICIPANTES } & $\begin{array}{l}\text { Representado - pessoa, lugar, coisa (concreta ou } \\
\text { abstrata, animada ou inanimada) de que se está } \\
\text { Objetos e elementos presentes em uma compr } \\
\text { gráfico-visual. }\end{array}$ \\
$\begin{array}{c}\text { falando, escrevendo ou produzindo imagens. } \\
\text { Interativo - aqueles que interagem ao ler a } \\
\text { imagem, ou seja, o produtor e o leitor do texto } \\
\text { imagético. }\end{array}$ \\
Ausência ou menor detalhamento do pano de & $\begin{array}{l}\text { Processos simbólicos - ocorrem quando há } \\
\text { presença de elementos na imagem que não são } \\
\text { intrínsecos a ela e que acrescentam valor ou }\end{array}$ \\
\hline
\end{tabular}

\footnotetext{
${ }^{5}$ Fontes: http://www12.senado.leg.br/noticias/materias/2016/05/02/criado-por-lei-o-dia-nacional-de-combate-aobullying

e http://www2.camara.leg.br/camaranoticias/noticias/EDUCACAO-E-CULTURA/507956-SANCIONADA-LEI-DO-DIANACIONAL-DE-COMBATE-AO-BULLYING.html?utm_campaign=boletim\&utm_source=agencia\&utm_medium=email.
} 


\begin{tabular}{|c|c|}
\hline fundo (foco nos participantes e seus atributos). & gnificado aos participantes. \\
\hline $\begin{array}{l}\text { PROCESSOS NARRATIVOS } \\
\text { Participantes (representados) conectados por um } \\
\text { vetor, inseridos em pano de fundo que indique as } \\
\text { circunstâncias de tempo e espaço nos quais o } \\
\text { evento se desenvolve. }\end{array}$ & $\begin{array}{l}\text { Processos de ação - o vetor origina-se do "ator" } \\
\text { em direção ao "objeto". No processo intransitivo, } \\
\text { há somente um participante e um vetor. Atores } \\
\text { são os participantes mais evidentes que instigam o } \\
\text { processo transitivo (dois participantes e um } \\
\text { vetor). } \\
\text { Processos de reação - o vetor é formado pela } \\
\text { direção do olhar de um ou mais participantes } \\
\text { representados, partindo do "agente" (humano ou } \\
\text { animal) em direção aos fenômenos. Em processos } \\
\text { intransitivos, os participantes olham para algo } \\
\text { exterior à imagem. }\end{array}$ \\
\hline $\begin{array}{l}\text { FUNÇÃO DE COMPOSIÇÃO } \\
\text { Significados representacionais e interativos. o } \\
\text { valor da informação e o lugar em que se } \\
\text { apresentam no todo da imagem ou da página } \\
\text { multimodal (texto e imagem). }\end{array}$ & $\begin{array}{l}\text { O dado (à esquerda - informação já conhecida do } \\
\text { leitor/viewer) e o novo (à direita - informação } \\
\text { desconhecida). } \\
\text { O real (abaixo - especifica ou detalha a proposta) } \\
\text { e o ideal (acima - ausente ou generalizado ou } \\
\text { idealizado). } \\
\text { O centro (contém a informação principal) e a } \\
\text { margem (contém elementos acessórios ao que } \\
\text { está no centro). } \\
\text { Saliência (recursos que atraem a atenção do leitor } \\
\text { para determinados pontos (cores, tamanho, } \\
\text { disposição em } 1^{\circ} \text { e } 2^{\circ} \text { planos). }\end{array}$ \\
\hline
\end{tabular}

Fonte: Elaborado pelo autor, com base em Galvão (2015) e Nascimento, Bezerra e Heberle (2011).

\section{O muro}

Conforme dito anteriormente, a narrativa visual do painel pintado no muro representa a luta pelo surgimento da EBT e seu prestígio como centro de excelência em educação bilíngue para surdos. Para a análise, destacam-se os participantes representados, o dado e o novo, a projeção e saliência e os símbolos nele contidos. A orquestração entre essas categorias obedece ao princípio de integração de recursos semióticos, já que cada um deles possui determinadas potencialidades e limitações na construção de sentidos, porém funcionam de forma integrada para a formação do significado global (GALVÃO, 2015, p. 70). 


\section{Participantes Representados}

Figura 7 - Participantes representados no muro

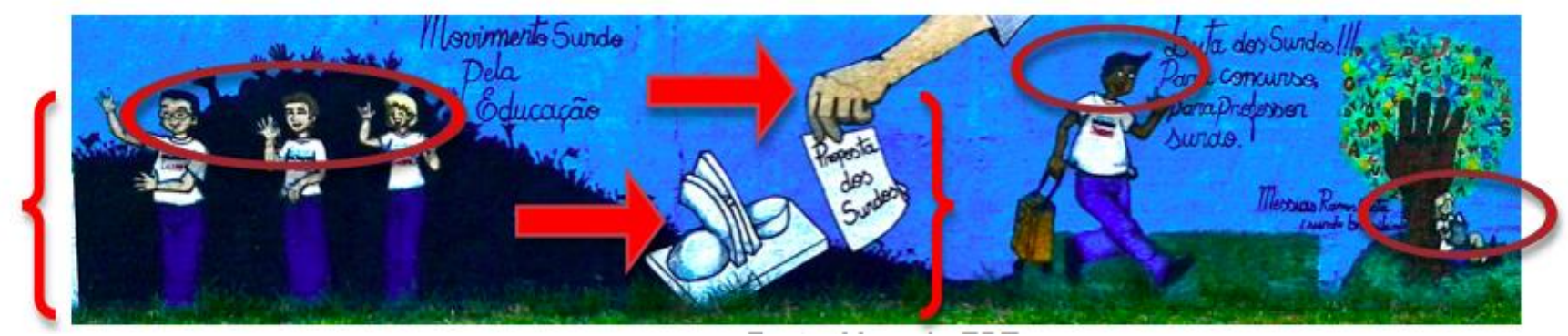

Fonte: Muro da EBT.

Há seis participantes representados na Figura 7 - três humanos e três que fazem alusão a movimentos ou instituições, portanto, carregam traço humano. Começo da esquerda para a direita: há três pessoas em primeiro plano, vestindo uma camiseta branca, na qual pode-se ler "Escola Bilíngue para Surdos". Os vetores dos braços demonstram que todos estão fazendo uso da língua de sinais, especialmente a moça de cabelos louros, cuja configuração de mãos resulta no sinal universal "eu te amo”, o qual mostra o dedo mindinho, indicador e polegar em riste. Estes podem ser tanto membros da comunidade surda quanto professores reivindicando a regulamentação da Escola Bilíngue. A Figura 8, a seguir, consegue mostrar tais detalhamentos com mais nitidez, pela ampliação das imagens.

Figura 8 - Participantes representados no Movimento Surdo pela Educação

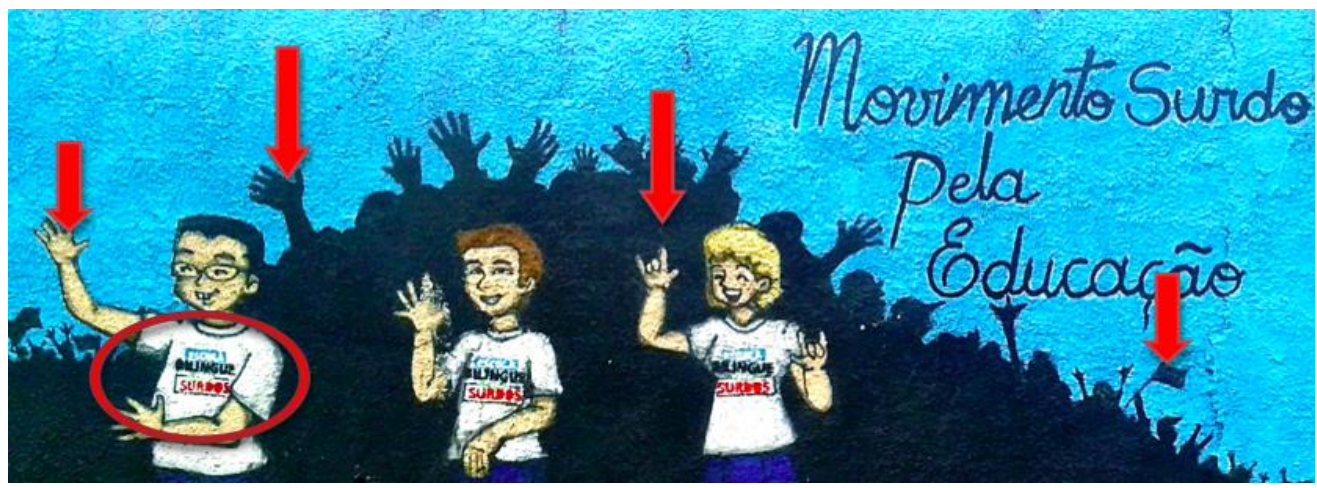

Fonte: Muro da EBT. 
Atrás deles, como pano de fundo, há uma grande montanha negra, cujas bordas superiores estão coroadas por mãos e bandeiras, simbolizando a mobilização social que deu impulso ao Movimento Surdo pela Educação, graficamente escrito na tela. Considero este um dos mais importantes participantes representados no mural, pois trata-se da personificação do participante interativo, o viewer, que somos todos nós: surdos e ouvintes, alunos e professores, membros da comunidade surda e/ou simpatizantes. Sua magnitude é vasta, já que, tanto em tamanho quanto em extensão, a montanha negra percorre mais da metade do painel. Tal informação será mais relevante quando tratarmos de projeção e saliência, a posteriori.

O Congresso Nacional também representa os legisladores, os quais receberam a proposta levada pela comunidade surda, personificada pela grande mão que entrega o documento contendo a proposta de criação da EBT. Até este pedaço do mural, observase que os vetores compõem o movimento das ações da direita para a esquerda.

Já o próximo participante, o qual também veste a mesma camiseta branca, é negro, carrega uma mochila de rodas em uma mão e fala "eu te amo", em língua de sinais, com a outra. Ele marca a mudança vetorial da esquerda para a direita, numa alusão à mudança dos empreendimentos, ou seja, se antes a onda de esforços voltava-se para a criação da EBT, ela agora segue rumo à manutenção dessa instituição, a qual trará as ferramentas de que o surdo precisa para garantir as condições mínimas que o possibilitarão concorrer a cargos públicos, conforme expresso na legenda. Além disso, existe uma questão-chave em termos de identidade: a formação do professor surdo como modelo bem-sucedido para as próximas gerações de alunos surdos. Este é o caso do professor Messias Ramos Costa6, professor surdo da Universidade de Brasília, cujo nome está estampado no muro. O peso desse recurso semiótico - a escrita do nome de

\footnotetext{
${ }^{6} \mathrm{Em}$ busca de mais referências, compartilho as informações de destaque do perfil do professor Messias, retiradas de seu blog https://blogdomessias.wordpress.com/2010/06/15/perfil/, em 30/7/2016. Meu nome é Messias Ramos Costa. Nasci em Brasília - DF. Sou surdo. Professor de Libras concursado pela Universidade de Brasília, onde fui o primeiro professor substituto de Língua de Sinais Brasileira - LSB - no Curso de Letras do Departamento de Linguística, Português e Línguas Clássicas, e atuei por quase dois anos. Estou como Diretor Regional da Federação Nacional de Educação e Integração dos Surdos FENEIS/DF (www.feneis.org.br), desde 20 de Agosto de 2006. Tenho licenciatura plena em Pedagogia e especialização em Língua de Sinais Brasileira e a Licenciatura em Letras-Libras da Universidade Federal de Santa Catarina - UFSC, no polo na UnB. Fui tutor do Projeto 500, um projeto que oferece curso de Libras para os servidores federais. Em 2008, ingressei no Mestrado do Curso de Pós-Graduação em Linguística da Universidade de Brasília - UnB. Criei o Jornal Virtual para surdos e ouvintes e o Projeto Tom do Pantanal em Libras, que trata da relação entre docentes e alunos no processo de inclusão nas escolas regulares. Fui membro da equipe "OK", cujo site apresenta piadas, notícias, livros, links e mais, tudo em Língua de Sinais Brasileira. Atuei como professor surdo, durante três anos e meio, em escolas regulares da Secretaria de Educação - GDF. Na Escola Classe 01 de Brazlândia, como Apoio Pedagógico e como Coordenador de Informática. Essa função também foi desempenhada na Escola Classe 21 de Taguatinga, durante seis meses.
} 
um indivíduo surdo bem-sucedido -, confere a dignidade, a liberdade e o respeito necessários para manter a autoestima de milhares de crianças que, ainda hoje, sofrem com a pulverização de estigmas e preconceito tão enraizados em nosso país.

Por fim, há uma pequena estudante, usando a mesma camiseta dos demais, lendo embaixo de uma árvore. Ela representa as gerações de jovens surdos que serão beneficiados pela educação bilíngue. A análise deste participante só será completa mais adiante, ao mencionarmos os processos simbólicos, materializados pela árvore na qual a estudante se escora.

\section{O dado e o novo}

Figura 9 - 0 dado e o novo 1

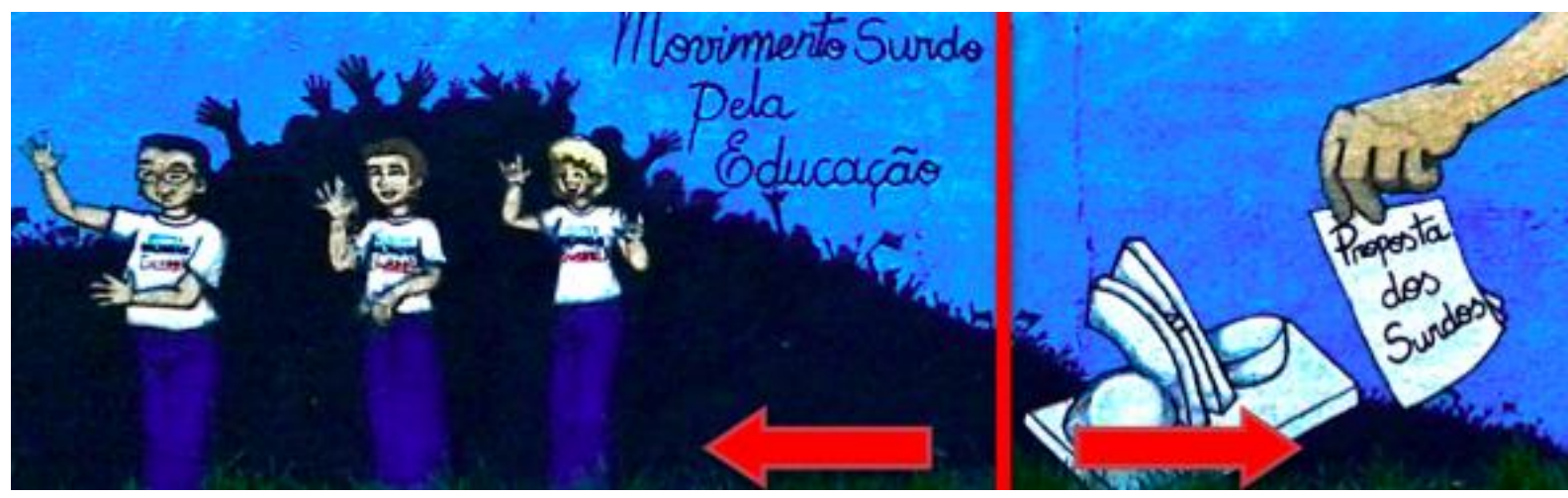

Fonte: Muro da EBT.

$\mathrm{Na}$ nossa cultura ocidental, a orientação da leitura é feita da esquerda para a direita. Neste raciocínio, a informação já posta, mais geral, previamente conhecida é, normalmente, posicionada à esquerda e o que ainda é desconhecido, vanguardista ou está por vir, geralmente, encontra-se à direita na imagem. No muro, há dois momentos distintos em que o antes e o depois compõem a cronologia dos eventos: o primeiro pode ser observado pela Figura 9, na qual o movimento da comunidade surda gerou a proposta levada à Câmara Legislativa.

O segundo pode ser visto na Figura 10, a qual mostra que, após apresentada a proposta dos surdos, a luta passa a ser o fomento da educação bilíngue para que haja concursos para professores surdos. 


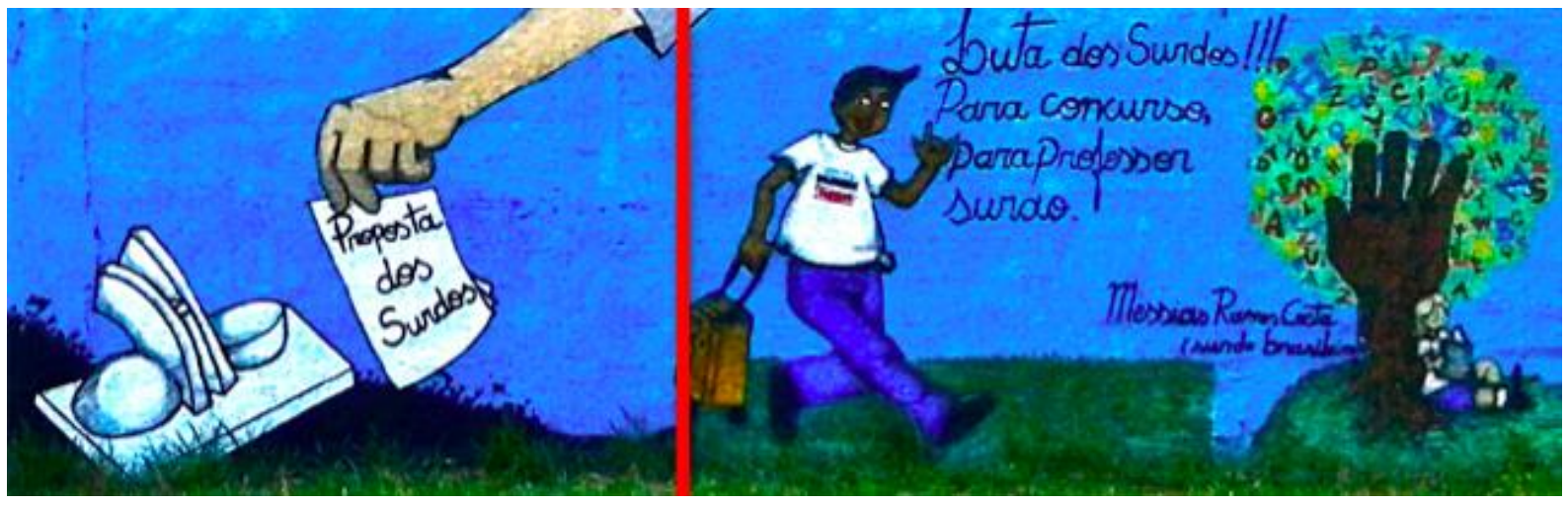

Fonte: Muro da EBT.

\section{Saliência}

Esta é uma das categorias mais contundentes para o muro porque é por meio dela que se pode medir o peso que alguns elementos da composição têm quando comparados a outros.

Quando a composição é o modo de integração, a saliência é julgada com base em pistas visuais. Os leitores (viewers) são intuitivamente capazes de julgar o 'peso' dos vários elementos de uma composição e, quanto maior o peso de um elemento, maior é a sua saliência. Esta, mais uma vez, não é objetivamente mensurável, mas resulta da complexa interação entre vários fatores: tamanho, exatidão de foco, contraste de tons (áreas com alto contraste de tons - por exemplo, bordas entre preto e branco têm grande saliência), contraste de cores (por exemplo, o contraste entre cores altamente saturadas e cores 'suaves' ou o contraste entre vermelho e azul), posicionamento no campo visual (os elementos não somente tornam-se 'mais pesados' à medida em que são movidos para o topo, mas também parecem 'mais pesados' quanto mais forem colocados para a esquerda, devido a uma assimetria no campo visual), perspectiva (objetos em primeiro plano possuem mais saliência do que objetos no pano de fundo e elementos que se sobrepõem a outros possuem mais saliência do que os elementos aos quais se sobrepõem) e, também, fatores culturais bem específicos, tais como a aparência de uma figura humana ou um símbolo cultural potente (KRESS \& VAN LEEUWEN, 1996, p. 202, tradução $\operatorname{minha})^{7}$

\footnotetext{
${ }^{7}$ Whencompositionistheintegrationmode, salienceisjudgedonthebasisof visual clues. The viewersofspacialcomposition are intuitivelyabletojudgethe 'weight' ofthevariouselementsof a composition, andthegreatertheweightofanelement, thegreater its salience. Thissalience, again, isnotobjectivelymeasurable, butresultsfromcomplexinteraction, a complex trading-off relationshipbetween a numberoffactors: size, sharpnessoffocus, tonal contrast (areasof high tonal contrast - for instance, bordersbetweenblackandwhite - have high salience), color contrasts (for instance, thecontrastbetweenstronglysaturatedand 'soft' colors, orthecontrastbetweenredand blue), placement in the visual field (elementsnotonlybecome 'heavier' as they are movedtowardsthe top, butalsoappear
} 
Gostaria de lançar destaque para as cores e o tamanho de certos participantes representados, bem como os elementos colocados em primeiro e segundo planos. As cores predominantes são azul, preto, verde e branco. A mescla de cores neutras e frias traz realce para o branco, que se destaca na blusa usada pelos participantes humanos, na cor do Congresso Nacional e na cor do papel com a proposta dos surdos. Esses são os elementos de maior saliência na narrativa. Em oposição ao branco, a grande massa do movimento que mobilizou a comunidade surda e ouvinte é representada na cor preta, a qual equaliza as diferentes identidades dos diversos indivíduos que atuam nesta causa e, de certa forma, os harmoniza.

Quanto ao tamanho relativo dos elementos, enfatizo a desproporção como algo extremamente marcante aqui. Em primeiro lugar, a estudante surda sentada embaixo da árvore, no extremo direito da imagem, é exageradamente menor do que os demais participantes humanos representados, o que me faz concluir que o produtor da narrativa confere acentuada magnificência ao indivíduo letrado e militante. 0 tamanho diminuto da estudante equivale à sementinha que precisa do solo fértil (EBT), água (professores) e clima favoráveis (família e sociedade) para desenvolver-se e florescer até atingir sua total emancipação.

No mais, entendo que o movimento social pela educação, representado pela colossal montanha negra e pela mão gigante que detém a proposta dos surdos é a projeção da sociedade como um todo, a qual é maior do que o Congresso. Cumpre ressaltar que a política é artefato cultural relevante para o surdo. Há, aqui, a mensagem do poder que a mobilização social tem perante seus representantes políticos. Pode-se observar que tanto em tamanho quanto em extensão, o movimento se destaca em segundo plano, da esquerda para a direita, em curva decrescente, alocando os elementos em primeiro plano a um destaque sutilmente menos acentuado.

\section{Atributos Simbólicos}

Os processos simbólicos denotam o que é ou o que determinado participante significa. Segundo Nascimento, Bezerra e Heberle (2011), ocorrem quando a imagem

'heavier' thefurtherthey are movedtowardstheleft, duetoanasymmetry in the visual field), perspective (foregroundobjects are more salientthan background objects, andelementsthatoverlapotherelements are more salientthantheelementstheyoverlap), andalso quite specific cultural factors, such as theappearanceof a human figure or a potent cultural symbol (KRESS; VAN LEEUWEN, 1996, p. 202). 
apresenta atributos que não são dela característicos, mas acabam por conferir valores que adicionam significado. Kress e van Leeuwen (1996, p. 105) apontam que atributos simbólicos são objetos que têm uma ou mais das seguintes características:

- São postos em destaque na representação de uma maneira ou de outra, por exemplo, por serem colocados em primeiro plano, por terem tamanho exagerado, por serem particularmente bem iluminados, por serem representados em detalhes especialmente refinados ou com enfoque preciso, ou ainda por suas cores e tons bem visíveis;

- $\quad$ Em geral, parecem estar, de certa forma, fora de lugar;

- $\quad$ São convencionalmente associados a valores simbólicos.

Desta sorte, o atributo simbólico de maior destaque são as mãos, partes do corpo que dão voz ao surdo, presentes nas quatro figuras a seguir:

Figura 11 - Mãos que falam, lutam e amam

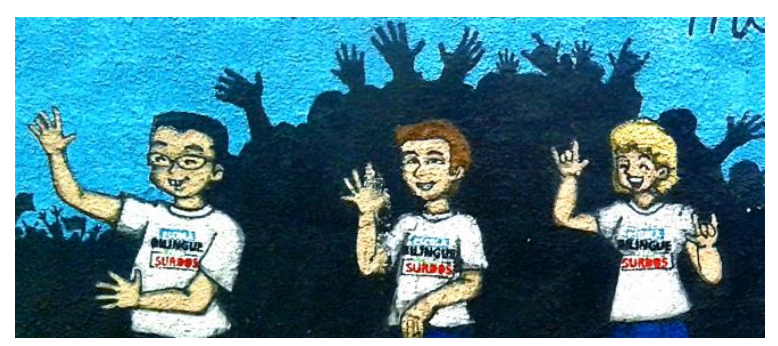

Fontes: Muro da EBT.

Figura 13 - A mão que propõe

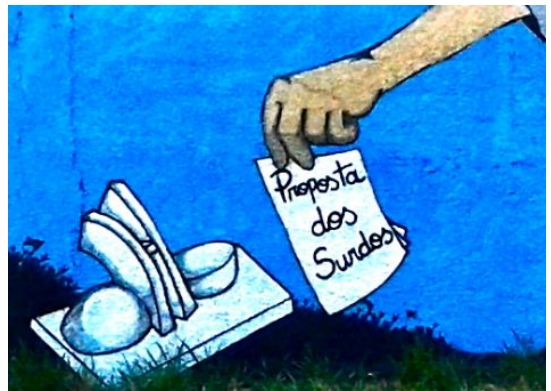

Fontes: Muro da EBT.
Figura 12 - A mão que ama

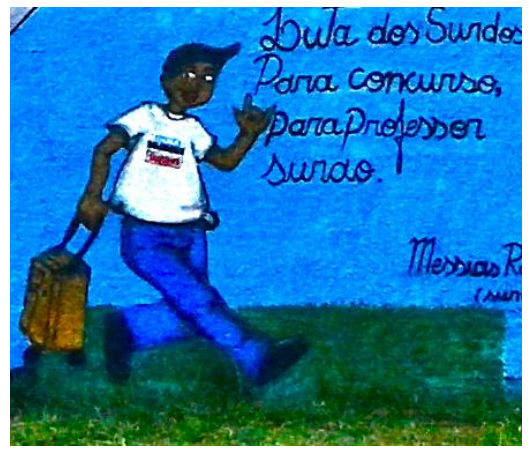

Figura 14 - A mão que sustenta e protege

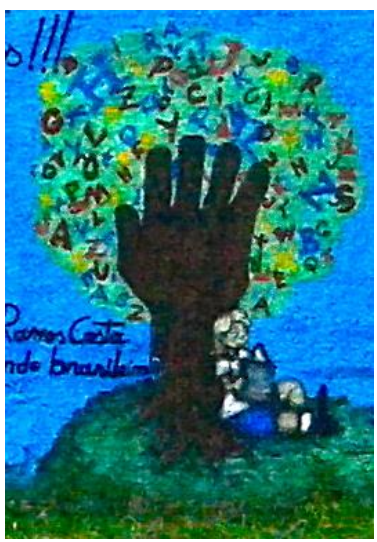


Interessante é notar a construção de ícones entre a cultura ouvinte e a surda. Para mim, que ouço, a mão pode simbolizar diversos conceitos. Em termos de comunicação com outros, especialmente devido à prática acadêmica, vejo as mãos como emblemas da escrita - dificilmente entenderia que elas também falam, sentem e amam se não fosse por esta investigação. Vale dizer que a mesma mão que escreve para estabelecer diálogo também sinaliza; logo, há novos potenciais de significados associados a esse elemento que é absolutamente icônico para os surdos.

\section{O mural}

De acordo com Royce (2007, p. 66), a leitura de determinada imagem pressupõe a interação de três elementos que remetem às metafunções de Halliday - interpessoal, ideacional e textual - quais sejam os participantes representados e os interativos, além dos elementos estruturais e coesivos do texto imagético. A coocorrência dos modos verbal e visual, que se complementam semanticamente para produzir um único fenômeno textual é chamada de complementaridade interssemiótica. É por meio desse princípio que se entende a razão pela qual, no caso do mural no pátio da EBT, o modo verbal só ganha sentido a partir do momento em que outros recursos semióticos (diferentes daqueles típicos da linguagem escrita) são usados.

Ora, se o objetivo do mural é chamar atenção do transeunte, os produtores do texto imagético dispõem de inúmeros recursos visuais que servirão para capturar o olhar de quem passa, entre eles: as cores, o formato, o tamanho, as caixas de texto, os quadros, etc. A complementação entre recursos retira a escrita de um estado puramente gráfico, estático e monocromático para outro mais dinâmico, com diversas camadas e multicor, ou seja, as regras de composição textual obedecem ao mesmo princípio de complementaridade inter-semiótica. Como o objetivo é tornar os alunos surdos bilíngues, partindo do pressuposto de que o surdo é indivíduo usuário de uma língua espaço-visual, a combinação dos recursos semióticos dos modos visual e verbal favorecerá a aquisição do português escrito. Neste passo, encaminho-me para a análise do mural produzido pelos alunos. 


\section{Os participantes}

Ambos participantes representados e interativos possuem fundamental importância para a análise multimodal do mural. De acordo com a sequência didática, os participantes interativos, ou seja, os produtores e os consumidores (viewers) do texto imagético, são surdos. Dentre os vários temas propostos, um grupo de alunos ${ }^{8}$ escolheu 0 "Bullying" como o mais relevante a ser estudado e, consequentemente, ressemiotizado para fora da sala de aula. Essa ressemiotização implica em que o tema trabalhado intraclasse seja transposto extraclasse, em forma de mural, ilustrando, assim, o processo de distribuição dos textos ${ }^{9}$, os quais, por conseguinte, são postos ao alcance dos demais estudantes da escola. Estes, por sua vez, também foram submetidos ao mesmo processo, porém com tema diverso, ou seja, "Violência contra a Mulher". 0 intercâmbio dos temas trabalhados atinge a todos os demais discentes da EBT, uma vez que a ressemiotização dos textos escritos em murais favorece o letramento em português escrito de pessoas visuais, surdas.

Já os participantes representados de destaque no mural figuram pessoas em atos de violência ou intimidação, atuando tanto como autores quanto vítimas de bullying, como mostram as Figuras 15 e 16.

Figuras 15 e 16 - Participantes Representados no mural da EBT
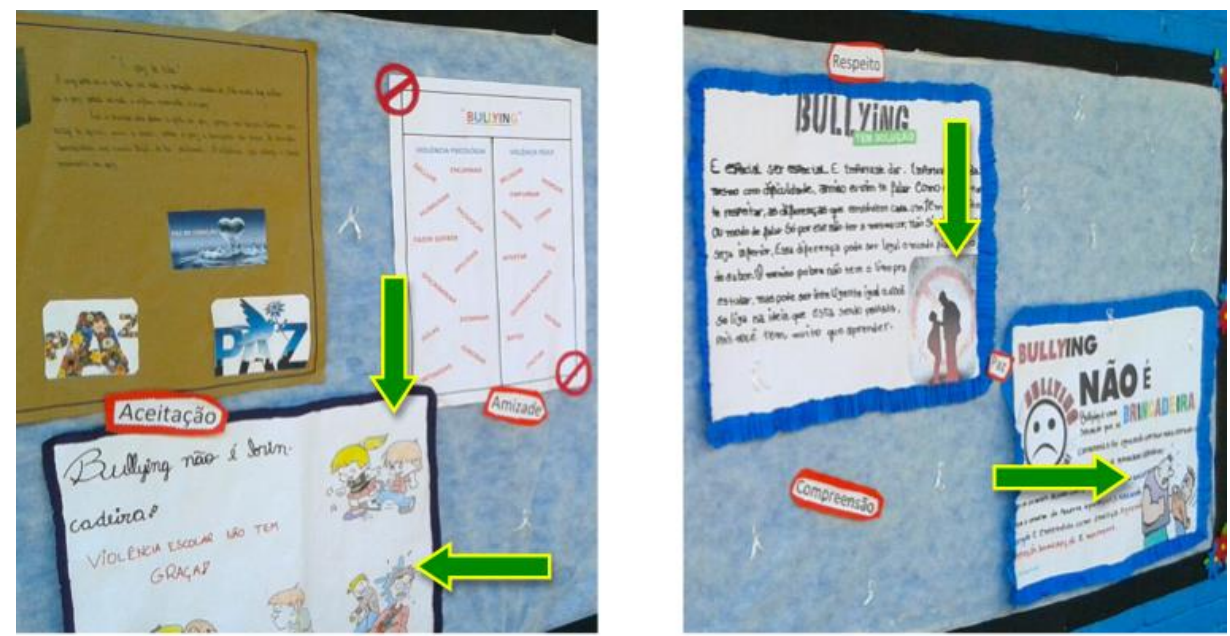

Fonte: Kit de aula enviado pela professora de português, via correio eletrônico.

\footnotetext{
${ }^{8}$ Pelo texto da sequência didática, não fica claro quem exatamente são os alunos que decidiram trabalhar com o tema bullying e, consequentemente, produziram este mural.

${ }^{9}$ O uso da palavra "texto", neste caso, condiz com a definição deste termo em ADC, ou seja, a materialização do discurso.
} 
É interessante observar que, na Figura 15, no cartaz à esquerda e abaixo, marcado com duas setas, as imagens têm maior proeminência em relação ao texto verbal, já que o tamanho e as cores da fonte não são tão salientes quanto o tamanho e as cores das imagens apontadas pelas setas. É possível identificar os personagens em atos de violência física e psicológica (FIGURA 17): fofoca, intimidação, arremesso de fluidos e pisadas no pé são as ações que marcam estes participantes.

Figura 17 - Zoom do cartaz no canto esquerdo

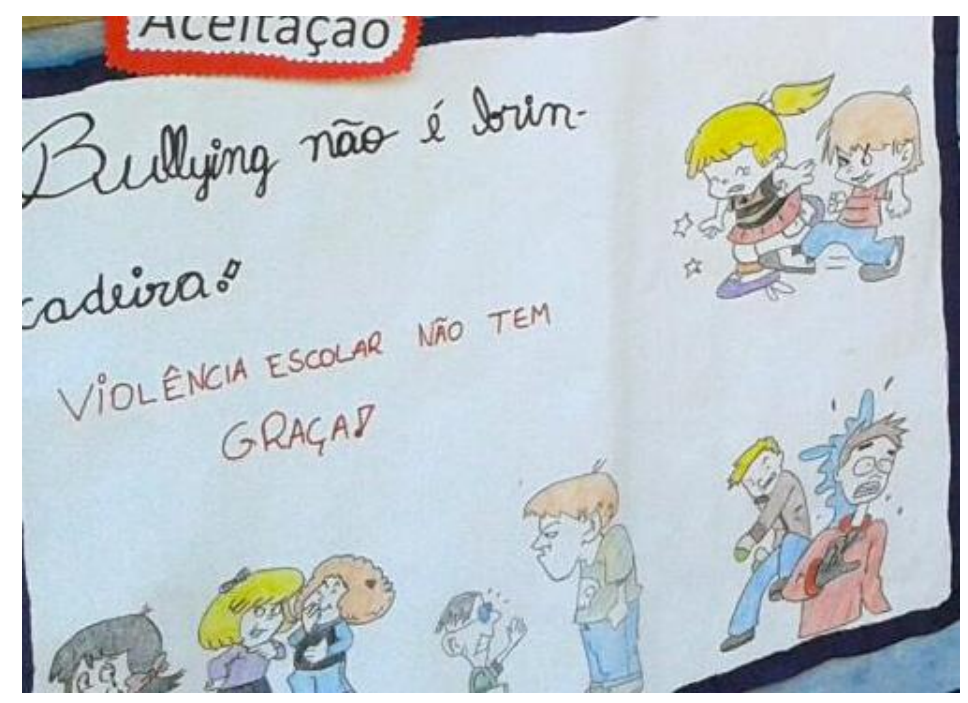

Fonte: Figura 15.

Em contrapartida, nos cartazes da Figura 16, existem mais textos verbais e menos imagens. Ao olhar para o modo verbal, percebemos a multimodalidade latente, pois os recursos semióticos de cor, tamanho e tipo de fonte realçam o título do cartaz e o diferem do corpo textual, que aparece em menor tamanho e é monocromático. Esta é a prova viva de que não há texto monomodal. Ainda com relação aos cartazes da Figura 16 (ambos com bordas azul marinho), pode-se observar a complementaridade intersemiótica atuando de diferentes formas. 


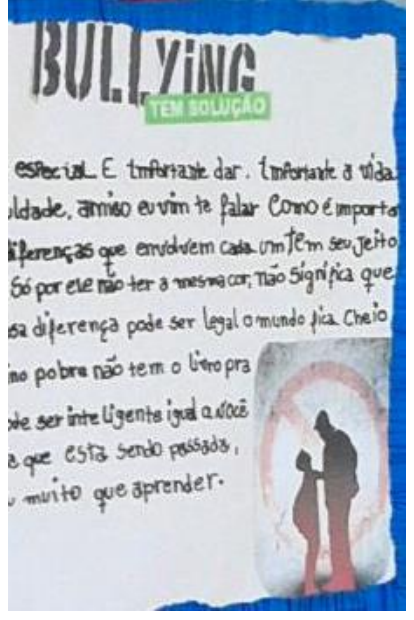

Fonte: Figura 16.

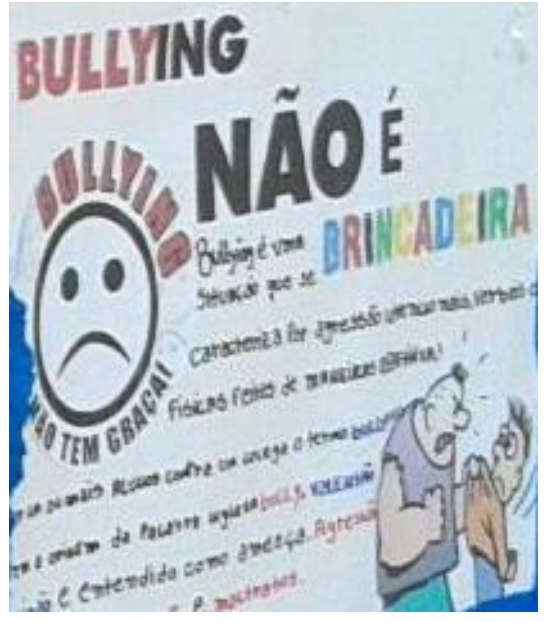

Fonte: Figura 16.

A Figura 18 mostra o título e subtítulo em destaque. Este porque traz as palavras escritas em fonte branca, com pano de fundo verde e aquele, pelo tamanho e tipo de fonte. Note que a imagem, no canto inferior direito, traz dois participantes, sombreados, cujas silhuetas mostram o seguinte cenário: um deles está em posição superior, de imponência, cujo vetor atua sobre o outro, em posição inferior, representando uma ação corporal icônica de intimidação. No pano de fundo, há o sinal de proibido, em vermelho, que é universalmente simbólico. 0 paralelismo verbal e visual é inegável.

O mesmo jogo visual e verbal pode ser visto no outro cartaz. A Figura 19 também traz dois participantes na mesma posição de intimidação. Contudo, o delineamento do desenho e as cores deixam mais nítida a ação do agressor, o qual está segurando o colarinho da vítima com uma mão e mostrando o punho cerrado, com a outra. A oposição a esta cena é feita pelo rosto redondo triste, em maior tamanho, à esquerda. 0 texto verbal destaca o advérbio de negação em maior tamanho, na cor preta (tom sério e austero), em contraste como o colorido da palavra “brincadeira" e o vermelho utilizado na palavra “bullying”. Indubitavelmente, o recurso semiótico das cores realça os elementos a que se quer dar destaque. Uma vez que cores, pano de fundo e tamanho se articulam com a imagem, passo para próxima categoria, que analisa justamente estes aspectos. 


\section{Saliência}

Para o mural, concentro a análise nas cores e tamanho dos recursos semióticos. Logo de início, pode-se observar que as paredes da EBT são pintadas na cor azul royal e o pano de fundo do mural tem um tecido azul bebê. A moldura escura do mural forma enquadres que se harmonizam com a cor marrom das portas, portais e janelas (FIGURA 29). Como esta categoria trata o peso que os elementos têm no todo composicional, a informação de maior saliência encontra-se em primeiro plano, ou seja, a mensagem no mural. De forma a corroborar essa ideia, Kress e van Leeuwen afirmam que

o que na língua é realizado por palavras classificadas como 'verbos transitivos' é visualmente realizado pelo que formalmente pode ser definido como vetores. O que na língua é realizado por preposições de lugar é visualmente realizado pelas características formais que criam o contraste entre primeiro e segundo planos (KRESS; VAN LEEUWEN, 1996, p. 46).

Figura 20 - Zoom do mural (parte superior esquerda)

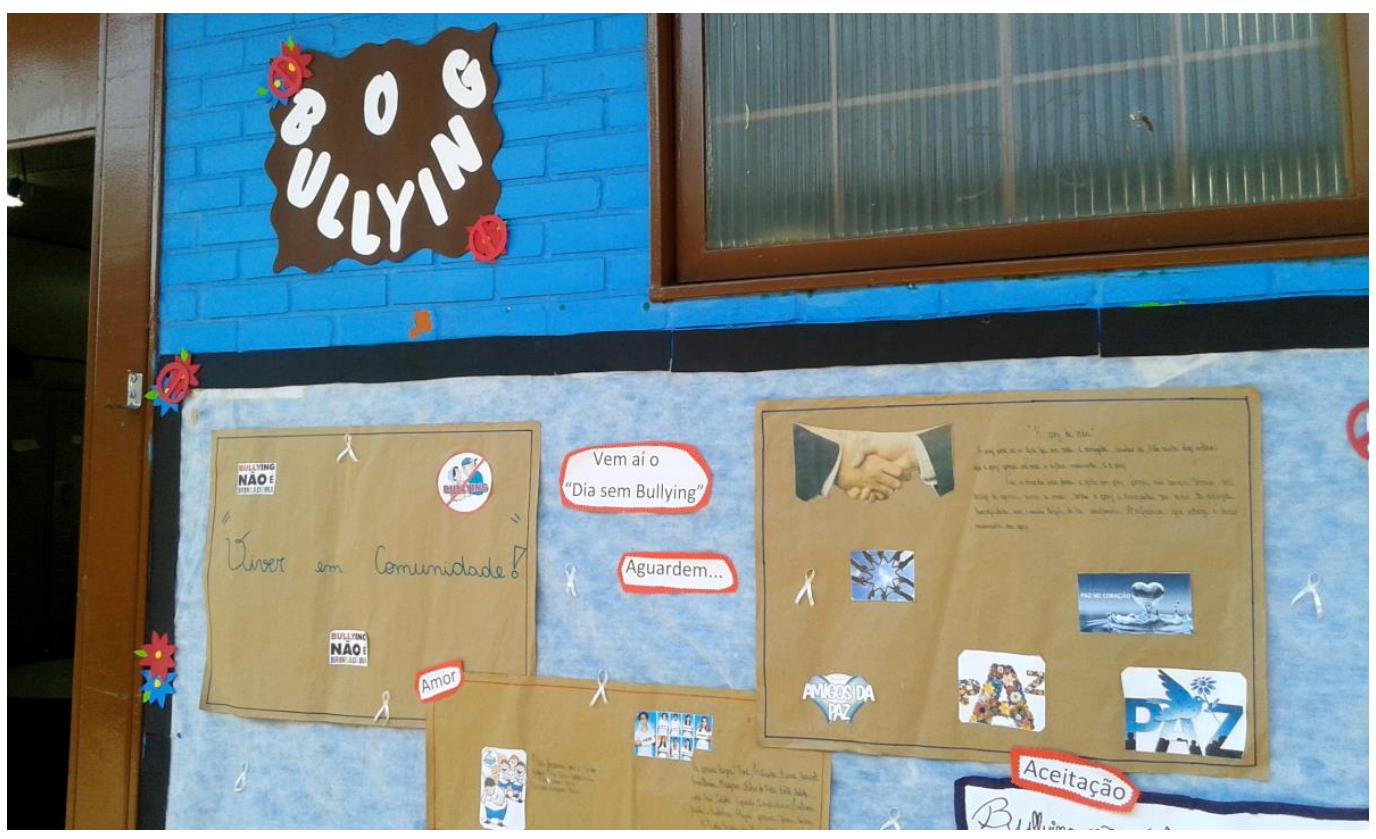

Fonte: Kit de aula enviado via e-mail. 
Figura 21 - Zoom do mural (à direita)

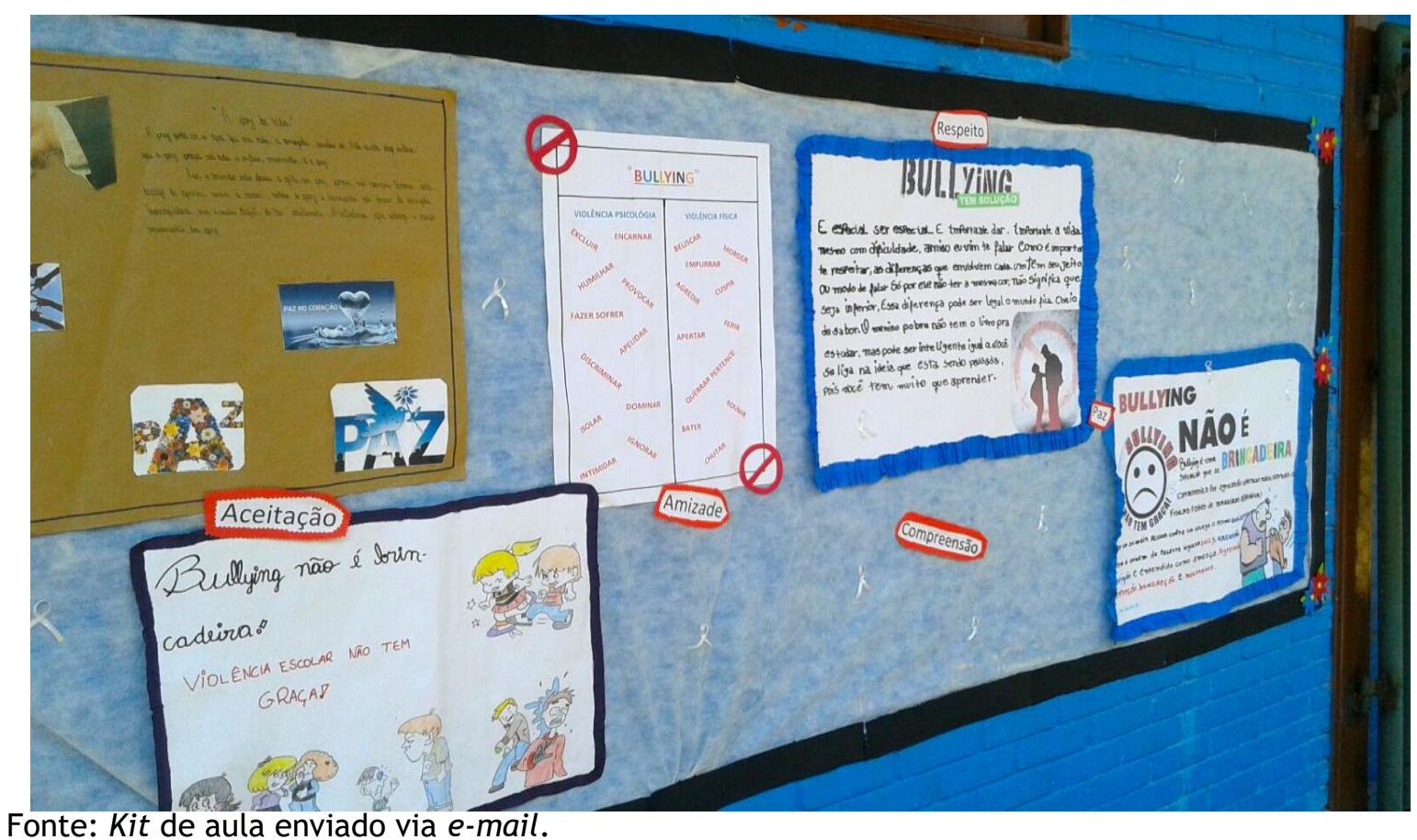

Fonte: Kit de aula enviado via e-mail.

A cor vermelha também é ferramenta poderosa de contraste. É por meio dela que o percurso de leitura é montado, em combinação com o tamanho ampliado das palavraschave associadas ao antônimo de bullying: amor, aceitação, amizade, respeito, compreensão e paz. De certa forma, todo o léxico empregado aqui condiz com os principais anseios de grupos sociais minoritários.

\section{0 real e o ideal}

Para Kress e van Leeuwen (1996), o valor das informações dispostas no topo do texto multimodal assume caráter ideal, louvado, hipotético ou, ainda, ausente. 0 que está na parte inferior da imagem tem mais proximidade do que é concreto, operante, real. Na Figura 20, vemos que a distinção entre topo e margem é feita da seguinte maneira: acima, está o título do mural "O Bullying”, escrito em letras arredondadas, na cor branca, em forma de semicírculo, montadas em primeiro plano sobre fundo marrom escuro que, curiosamente, rima com o tom do portal e da janela. Abaixo, está o mural multimodal, cujas cores, palavras graficamente expostas e imagens orquestram-se em mensagens de aceitação, respeito e paz. 
Tem-se, portanto, o oposto do que seria real ou ideal de acordo com os autores da Gramática Visual. Em se tratando de indivíduos visuais, a imagem é o real e o texto verbal é o ideal, conforme atestam os dados multimodais. É forçoso constatar a relevância que os aspectos culturais exercem, conferindo grande influência sobre o que cada grupo social pressupõe ser dado, novo, real e ideal.

\section{Considerações finais}

Figura 22 - Muros pichados na vizinhança da EBT

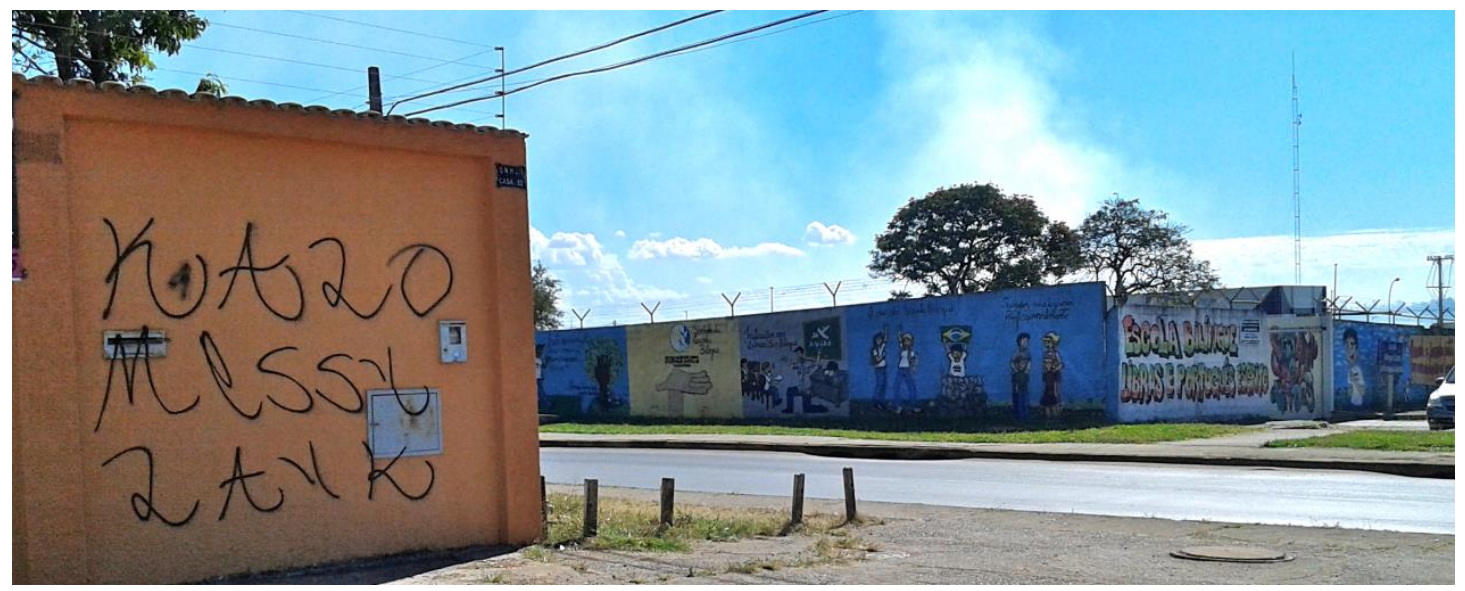

Fonte: Foto tirada pelo autor, em 5/5/2016, para este artigo.

O percurso de ressemiotização da linguagem oral e escrita na EBT perpassa o importante filtro afetivo construído entre professores ouvintes e alunos surdos. Tanto o muro quanto o mural retratam o empoderamento que é dado aos indivíduos visuais, aprendizes de português escrito como segunda língua. No muro, a história do surgimento da escola é contada por meio de imagens, cores e símbolos icônicos da cultura surda e participantes que também representam a comunidade ouvinte, sendo os textos verbais complementares às gravuras desenhadas. Os anseios e sonhos de prosperidade dos surdos, fomentados pelo direito à educação, extrapolam os muros da EBT e alcançam a comunidade local que, por sua vez, demonstra seu respeito, pois não há nenhuma pichação no muro desta escola, ao contrário do que pode ser visto nos muros das casas e prédios das cercanias (FIGURA 22). 
Por sua vez, o mural do pátio escolar demonstra como é possível realizar a releitura de um texto verbal e transformá-lo em texto predominantemente imagético. Os recursos semióticos visuais de cores, formas e tamanhos, juntamente com os participantes representados e interativos revelam que, apesar de já termos caminhado muito com a criação da EBT, ainda há longo percurso a ser feito para que o surdo seja respeitado e aceito em sua construção identitária diferente. Quando a comunidade ouvinte tornar-se bilíngue e aprender a língua de sinais, os surdos poderão sentir o mundo repleto de amor, aceitação, amizade, respeito, compreensão, paz e, consequentemente, inclusão.

\section{Referências}

BAKHTIN, M. Estética da criação verbal. Tradução feita a partir do francês por Maria Ermantina Galvão G. Pereira. Revisão da tradução Marina Appenzeller. 2a edição, São Paulo, Martins Fontes, 1997.

FAIRCLOUGH, N. Discurso e mudança social. Brasília: Editora Universidade de Brasília, 2001.

GALVÃO, R. Q. Do logocentrismo à Multimodalidade: uma análise crítica da comunicação política da Câmara dos Deputados do Brasil. Dissertação de mestrado apresentada ao Programa de Pós-graduação em Linguística, do Departamento de Linguística, Português e Línguas Clássicas. 201 f. Universidade de Brasília, 2015.

IEDEMA, R. Multimodality, resemiotization: extending the analysis of discourse as multisemiotic practice. SAGE: London, 2003, p. 29-57. Disponível em: <https://vcj.sagepub.com/content/2/2/29>. Acesso em: 30 mar. 2015.

KRESS, G.; VAN LEEUWEN, T. Reading Images: the grammar of visual design. London: Routledge, 2006.

KRESS, G; VAN LEEUWEN, T. Reading images: the grammar of visual design. London; New York: Routledge, 1996.

NASCIMENTO, R. G. do; BEZERRA, F. A. S.; HEBERLE, V. M. Multiletramentos: iniciação à análise de imagens. Pelotas: Universidade Federal de Santa Catarina, Linguagem \& Ensino, v. 14, n. 2, p. 529-552, jul./dez. 2011.

RODRIGUES, R. H. Análise de gêneros do discurso na teoria Bakhtiniana: algumas questões teóricas e metodológicas. Em: Linguagem em (Dis)curso, Tubarão, v. 4, n. 2, p. 415-440, jan./jun. 2004.

ROYCE, T. D. Intersemioticcomplementarity: a framework for multimodal discourse analysis. In ROYCE, T. D.; BOWCHER, W. L. (Eds.). New directions in theanalysis of multimodal discourse. Mahwah, New Jersey, London: Lawrence Erlbaum Associates, Inc. Publishers, 2007, p. 63-109.

VAN LEEUWEN, T. Introducing social semiotics. London: Routledge, 2005. 